\title{
So What's the Big Deal With Information Literacy in the United States?
}

\author{
Alease J. Wright
}

\begin{abstract}
Today's researchers have access to vast information, whether within the library or any place that provides access to the Internet, and frequently the access is free of charge. Such places can include school, home, office, restaurants or coffee houses. Access to information is available from smart and handheld devices such as Smartphones, as well. But now, more than ever a researcher must have a discerning sense of authoritative information. Information seeking has become a rapidly growing trend across society. And as technology continues to evolve, how we seek information and determine its authenticity will present challenges for teaching users how to remain information literate. Additionally, one cannot be information literate without the development of related skills such as critical thinking. Since the United States Department of Labor's well-know SCANS report (Secretary's Commission on Achieving Necessary Skills) published in 1991, other organizations have emphasized the need for information literate workers. Such organizations include the National Forum on Information Literacy and Project Information Literacy
\end{abstract}

Keywords United States • Information Literacy $\cdot$ Critical thinking $•$ Business needs

\begin{abstract}
A speech delivered at the seminar during the International University Student Information Literacy Competency Invitational Contest, which was, as a part of 1st Wuhan University Student Organization International Exchange Summer Camp, hosted by SIM, Wuhan University, July 13, 2010. It has been updated, with the author's article entitled "Big Deal with Information Literacy in the United States", for republication here.
\end{abstract}

Alease J. Wright: MLS, Ed.D, Springdale, MD, USA. An IBM retiree, former librarian and adjunct professor at Prince George's Community College in Maryland, has worked extensively with first year college students. Her re-search interests involve preparing academic librarians how to teach, and teaching and learning concepts. Comments and questions can be sent to: ajchristy@hotmail.com

\author{
A. J. Wright $(\bowtie)$ \\ Springdale, MD, USA \\ e-mail: ajchristy@hotmail.com \\ C. Chen, R. Larsen (eds.), Library and Information Sciences, \\ DOI 10.1007/978-3-642-54812-3_2, (C) The Author(s) 2014
}




\section{Background and History}

Libraries in the United States have undergone extensive change in the past 25 years. Prior to the 1980's research was performed primarily using printed sources such as books, maps, and indexes to periodicals. Online research existed during that era, but only by librarians, and usually at a cost per search. Librarian-student interaction either involved giving directions, or conducting library tours (Mercado 1999; Branch and Gilchrist 1996).

But all of that changed with the expansion of technology and its infusion into the library's walls. Today, information users now have access to vast amounts of information within the walls of the library, as well as outside of the building. Enter the Internet, that conglomeration of special telecommunication protocols using telephony, connecting computer servers from anywhere in the world to everywhere in the world, allowing access to various kinds of information, and by anybody who knows how to navigate the World Wide Web. Twenty-eight years ago, John Naisbitt (1982) author of Megatrends, predicted such effects of the information explosion.

Students can easily retrieve information for their research purposes. But easy access does not always mean retrieval of authoritative information. The American Library Association (ALA) recognized this dilemma and in1989 convened a committee that produced a presidential report and proclamation deeming information literacy one of the key skills for the twenty first century. Information literacy is a set of abilities requiring individuals to "recognize when information is needed and have the ability to locate, evaluate, and use effectively the needed information" (American Library Association, Presidential Report 1989).

Soon after the proclamation and the publishing of the report, and as a response to the presidential committee's recommendations on information literacy, Patricia Senn Breivik founded the National Forum on Information Literacy. The organization's web site describes how education, library and business leaders agreed that "no other change in American society has offered greater challenges than the emergence of the Information Age."

The Association of College and Research Libraries (ACRL) followed up on the ALA's 1989 proclamation by developing a set of standards for higher education. The five standards address the need for an information literate student to determine, access, evaluate, incorporate and use information effectively, ethically and legally (ACRL 2000).

\section{Why Information Literacy is so Important}

In 1990, the United States Department of Labor called for an examination of the skills required for the workplace by the twenty first century. What emerged was a report known as the SCANS report, or Secretary's Commission on Achieving Necessary Skills, What Work Requires of Schools for Americans 2000. To create the report, researchers on the commission held discussions with "business owners, public employers, unions, workers, and supervisors in plants, shops, and stores" 
(Department of Labor 1992). The commission reported that upon "graduation from high school, students must have a new set of competencies and foundation skills... to make their way in the world" (p. i). The report identified eight competencies, one of which deals with the use of information, that is, "acquiring and evaluating data, organizing and maintaining files, interpreting and communicating, and using computers to process information..." (p. iii).

Sharon Weiner, NFIL co-chair, professor and W. Wayne Booker chair in Information Literacy at Purdue University recently wrote in an Educause article that "college students think of information seeking as a rote process and tend to use a small set of resources no matter the problem. Collaborative efforts between faculty, librarian, technology professionals and others can develop students who graduate with information literacy competency." Weiner concludes that being information literate empowers individuals and is a skill that can be used throughout their life (Weiner 2010).

Information literacy is not meant to be an independently defined skill. One cannot be or become information literate without the development of other related skills such as critical thinking. The Partnership for the twenty first century (P21) is a national organization that advocates for twenty first century readiness. One such "readiness" skill it defines as a core competency skill is critical thinking. P21 issued a press release announcing that executives are looking for more skilled workers. Executives want to hire workers who are critical thinkers, problem solvers, workers who can collaborate, create and be innovative. The press release was the result of a recent survey conducted by the American Management Association.

Finally, the Educational Testing Service (ETS), known for administering college placement tests such as the SAT, GRE and the tests to assess English speaking and writing proficiency as a second language, created a panel in 2009 to develop a cutscore indicating good critical thinking skills. As a member of the panel made up of over 20 educators and librarians from around the United States, this author found the task to define a reasonable cut-score challenging and quite intense. Nevertheless, upon the completion of our efforts, the ETS issued the following statement as it introduced the new certification tool, iCritical Thinking TM, late last year: "To succeed in today's digital world, students and workers need to think critically and solve problems using a full range of information and communication technology (ICT) literacy skills" (Educational Testing Service 2009).

We can see how the need for information literacy has evolved and has become a critical skill for the twenty first century. This skill transcends academic requirements and is a skill, along with critical thinking and problem solving, valued by the workplace. In fact, information literacy is a lifelong learning skill.

Thus, we have arrived to today, in the second decade of the twenty first century, where embracing the need for information literacy and critical thinking are an integral part of the First Wuhan University's International Exchange Camp. As an information literacy advocate, it is heartwarming to see that the focus of this event is not only the management of information, but the development of information literate awareness as well. The academy has a large responsibility in creating such awareness and much of the efforts in the United States are being undertaken by aca- 
demic librarians. In fact, the emergence of information literacy has created a shift for academic librarians, from custodians and retrievers of information, to the role of teacher, teaching students how to become information literate (Wright 2007). As far back as 1905, Melvil Dewey predicted this new role when he described librarians as "teachers in the highest sense" (Vann 1978).

\section{How Information Literacy has Affected Librarians' Role}

The first part of this presentation has provided you with a background and history of information literacy. The next part of this presentation will emphasize the impact that information literacy has had in academic libraries in the United States. Part of this next section will demonstrate such impact through interaction with you. As undergraduate or graduate students, it might be safe to assume that you feel fairly competent in navigating the various sources for information retrieval in order to solve a problem, but let's find out how much you already know.

When you want to find an answer to a question how many of you use the popular search engines Google, Yahoo, and Bing? In the United States, Google has actually become a conversational verb whereby it is common to hear someone say "Google it!" when there is an information need. First year college students are cautioned by this author about using Google as their first resource. With the exception of Google Scholar, much of what is listed in the results may sound factual but can be misleading. Students are also warned about using Wikipedia. While Wikipedia is a good source to get general information about a topic or a person, it is not considered authoritative when it comes to doing academic research. The message here is simply to be discerning about the sources you use when you are doing academic writing. Authoritative sources such as the sources found on library web sites or within the library walls are best as your first selection. When you need articles, use the library's subscription databases. These contain thousands of articles from magazines, newspapers and journals about all sorts of topics. If you must use a search engine, try not to use web sites with the.com domain. Many of these sites are selling an idea, opinion, or product. To become information literate you must understand that one of the tenets of information literacy is to always honor copyright licenses which will help you avoid plagiarism.

\section{What's Your Information Literacy Aptitude?}

Let's see what you already know. Suppose you are taking a history class and you need to write a five-page paper on a famous war. Let's say you are given the following choices for sources to use during your research: encyclopedia, magazine and/or newspaper articles, text book, Atlas. Which ones would be appropriate to 
use? If you selected all of the choices, you would be on your way to writing a good paper. All of these sources are good secondary sources. You could also consider other possibilities such as interviewing someone who served in that war or any war to provide a soldier's perspective. Other creative approaches could be attending an historian's lecture on the subject, watching a TV documentary or listening to a radio program. The point I am hoping to get across is that doing a research project requires you to actively do several things: 1) determine you need information; 2) make a decision about the sources you could use; and 3) use and access the sources. These actions relate to several of the ACRL Standards for Information Literacy for Higher Education: Standard 1-Determine the need; Standard 2-Accessed information; and Standard 5-Used information effectively (ACRL 2000).

The problem we just discussed was a very basic research assignment. We will now try one a little more advanced. You have an assignment to write a paper for your Psychology class. You can select the topic. The paper must be five pages and you must use eight peer-reviewed sources to support your thesis. At the end of your five-page paper there should be an APA reference list. Your choices for resources are: text book, library databases, magazine and newspapers, encyclopedia, dictionary, APA Style Guide. Which source(s) would you not use?

If you chose not to use magazines and newspapers you would be on your way to being even more information literate. For this problem or assignment, you were asked to use peer-reviewed sources, or in other words, sources that are researchbased and have been reviewed by others in the discipline. Magazine and newspapers are not considered peer-reviewed sources. It is also important to mention here that when you are searching databases you may see other terminology indicating research-based and factual data such as "refereed" or "scholarly." Sometimes the word databases use is as simple as "academic." Your assignment required that you use the American Psychological Association (APA) style guide to list your sources on a reference page. This action keeps you honest indicating that the information used in your paper is not yours.

Taking a look at what information literate actions you demonstrated, you exercised the same three as in the basic problem, but in this problem you evaluated your choices a little more and you were ethical and legal with their use. Again, these actions relate to the ACRL Standards 1 and 2 as indicated above, and would include Standard 3- Evaluated sources critically, and another aspect of Standard 5 - Understood ethical and legal use.

Thus, you have been involved in an information literacy instruction session conducted by an academic librarian who has worked in the United States. In solving your research questions (using the two problems we discussed) we were engaged in a teaching and learning session. Rather than retrieve the information for you, you and I, through a different kind of librarian-student interaction, placed more focus on developing you as an independent researcher, a new role for the academic librarian.

The new academic librarian is also involved with designing the library's web site such that tutorials are available for assisting students as they work to become information literate. Librarians are teaching students how to think critically and how to 
construct search strategies for finding articles in subscription databases. The use of Boolean operators is an essential part to this latter activity, and is quite integrated in the task of identifying key concepts in a research problem. For example, consider the following research question: What effect does global warming have on the world's climate? In this question are key words or concepts that must be addressed in the articles a student would like to retrieve. Librarians ask students to think about which key words would they use. Once these are identified, the idea of using AND, OR, NOT as Boolean operators helps students narrow or broaden the results generated by their search. Other controlling characters such as parentheses and quotation marks can be used to suggest order of operation and to indicate special phrases. Once these practices feel comfortable for students they begin to realize how they might be able to reduce their frustration and often, the time it takes for them to do good research.

Equally as important as teaching students how to do research is the need for librarians to assess how much learning has taken place. In addition to using pre- and post tests as discussed by Hufford (2010), librarians are beginning to create other tools of assessment. For example, at Prince George's Community College, librarian Imogene Zachery (2008) developed an assessment tool based on the popular quiz show, Jeopardy! Her version of the game is called "Psychology 101 Jeopardy!" During a research instruction class, and after preliminary information has been disseminated, Professor/librarian Zachery asks students to pick a category from which a question is posed. When a student responds correctly, Zachery not only reinforces their learning but encourages everyone to participate in the assessment by presenting the person with the correct answer with a prize.

In 2006 this author developed a research instruction quiz that attempted to assess the primary elements of doing good research. Each student in a research instruction session was given the quiz at the beginning of the session so that they could become familiar with what would be covered. Additionally, they were told to listen attentively because they might hear the answers during the course of the session. They could choose to record their responses during the session or could wait until the last five minutes when everyone would be given a chance to record and review their answers. Examples of quiz questions and the correct answers follow.

Q: When identifying that you need articles from databases with scholarly journals what other terminology may you see? Please list them.

A: $\quad$ Refereed, Peer-reviewed, Academic

Q: Which are the best Internet domains to get factual information? Circle the correct answer(s).

A: $\quad$.edu.gov.org (All of these domains would be circled)

Q: What must I do to avoid plagiarism?

A: $\quad$ Always cite my sources

You may recall hearing these topics discussed during this presentation and perhaps you were able to respond with the correct answers because of your attentiveness. You have just participated in a form of self-assessment.

The assessment experience has been a rewarding one for this author for not only have areas where more teaching emphasis were identified based on students' 
response and comprehension calling for continuous revisions to the quiz, but observations of students' reactions have indicated that they might be able to leave the session with some degree of mastery of the research process using online resources. Such are the results that academic librarians hope to produce. In addition to the assessment tool, students in this author's research instruction sessions are usually given a list of tips for doing a research assignment to use as a reference point for current and future research projects. Although you are far beyond the first year, the list can be useful for your future assignments as well (See Appendix 1).

You may benefit from more advanced information regarding doing research and so the following are suggestions you might add to the list in Appendix 1: (1) Never use an in-text citation without appropriate reference information; (2) Always crosscheck your references; (3) When using databases, remember that the reference list should include the date when the information was accessed; (4) Regardless of the citation style you are required to use, be sure to follow the structure meticulously; and finally, (5) When in doubt during any step of the research process, check with a librarian.

\section{Summary}

While the technology explosion has made information easier to access, the challenge has come in determining what is deemed "good" or authoritative information. There are many organizations that are advocating for increasing the awareness and need for information literacy. In the United States, this need has brought forth a more active teaching role for librarians. Both Dewey and Simmons (2000) predicted this role, though Simmons has had the benefit of being around during the information technology explosion. Information literacy not only applies for the college student but has become a valuable skill sought by employers in the workplace as well.

It may be easier to give a student the information he or she needs, but teaching them how to find the information is akin to the old adage, "Give a man a fish and feed him for a day; teach him how to fish and you feed him for life" (Anonymous). The role for academic librarians can be summed up similarly. The task for the student is to understand the importance of becoming or being information literate, to learn the tenets and the tools, and to use them in every aspect of their life.

\section{The Big Deal with Information Literacy in the United States}

In the summer of 2010, the author presented and published a paper at Wuhan University's First Ever Information Literacy Competition, giving a personal view and status of information literacy practices in the United States. The following article represents an update. 
Libraries in the United States have undergone extensive change, especially in the last three decades of the twentieth century. Prior to that time information was solely found in books, indexes to periodicals, and maps. Any information stored in databases was accessed solely by librarians, and usually at a cost per search. Librarianstudent interaction either involved giving directions, or conducting library tours (Mercado 1999; Branch and Gilchrist 1996). Technology infiltrated the walls of the library and since then, they have never been the same. Information was now available in formats easily accessible by any user.

The American Library Association's presidential committee produced a report in 1989 proclaiming information literacy to be a key skill for the twenty first century (American Library Association, Presidential Report 1989). Equally as prescient was John Naisbitt (1982) who predicted in Megatrends such effects of this information explosion. Shortly after the ALA's proclamation, Patricia Senn Breivik founded the National Forum on Information Literacy. The organization's web site describes how education, library and business leaders agreed that "no other change in American society has offered greater challenges than the emergence of the Information Age" (www.infolit.org).

Today's researchers have access to vast information, whether within the library or any place that provides access to the Internet, and frequently the access is free of charge. Such places can include school, home, office, restaurants or coffee houses. Access to information is available from smart devices such as smartphones, as well. But now, more than ever a researcher must have a discerning sense of authoritative information.

At the beginning of the twenty first century, the Association of College and Research Libraries (ACRL) developed and published five standards to address the need for an information literate person. The Standards for Information Literacy addressed when to determine the need for information, how to access, evaluate, incorporate and use information effectively, ethically, and legally (ACRL 2000).

Since the United States Department of Labor's well-know SCANS report (Secretary's Commission on Achieving Necessary Skills) published in 1991, other organizations have emphasized the need for information literate workers. The National Institute for Literacy (2001), in their publication regarding the competency of adults for the $21^{\text {st }}$ Century, states that "....information and knowledge are growing at a far more rapid rate than ever before in the history of humankind" (p. 1). Sharon Weiner, NFIL co-chair, professor and W. Wayne Booker chair in Information Literacy at Purdue University wrote in an Educause article that being information literate empowers individuals and is a skill that can be used throughout their life (Weiner 2010). However, a recent study conducted by the Project on Information Literacy revealed that recent college graduates need a more comprehensive and varied approach to finding information required by their workplace environment. Students continue to rely solely on computer-related research skills learned in college rather than finding a way to integrate basic information tools such as the telephone (Head 2012).

Additionally, one cannot be information literate without the development of related skills such as critical thinking. The Partnership for the twenty first century (P21) advocates for twenty first century readiness. P21 issued a press release, the result of a 
survey conducted by the American Management Association, announcing that executives are looking to hire workers who are critical thinkers, problem solvers, as well as workers who can collaborate, create and be innovative. The Educational Testing Service, known for administering college placement tests such as the SAT, GRE and the tests to assess English speaking and writing proficiency as a second language, determined in 2009 a cut-score indicating good critical thinking skills. In their report they stated, "To succeed in today's world, students and workers need to think critically and solve problems using a full range of information and communication technology (ICT) literacy skills" (Educational Testing Service, iCritical Thinking, 2009).

Such is the evolution and demand for information literacy along with its companion skills, critical thinking and problem solving. No longer is the need for information tied to the libraries and the academy. Information seeking has becoming a rapidly growing trend across society. And as technology continues to rapidly evolve, how we seek information and determine its authenticity will present challenges for teaching users how to remain information literate.

\section{Librarians in the Academy}

To determine if library schools were preparing academic librarians for teaching information literacy, this author performed a study in 2007. Graduate school curriculums on web sites in the Middle States Commission Accrediting Region were examined to determine the emphasis on teaching skills. What the study revealed was that curriculums included course work related to information literacy but unlike the preparation for K-12 librarians, they did not require a demonstration of teaching skills (Wright 2007). A similar study was conducted a few years later when Bailey (2010) reviewed web sites and syllabi of 49 graduate schools. He concluded that for business information courses, more emphasis was placed on the theory of business information literacy than the practice of teaching users how to become information literate.

Practicing librarians are beginning to use active learning strategies. They develop information literacy games to assess how well students learn after a one-shot instruction session. One such librarian at a community college in Maryland created an information literacy Jeopardy! (C game. Students pick a category from which a question is posed. A correct response from a student makes them eligible for a prize (Zachery 2008). In Get in the Game, Smale (2012) describes how she developed a game called Quality Counts. Students are asked to critically examine websites and compare them to criteria listed in a quality model based on ACRL Information Literacy Standard 3: "The information literate student evaluates information and its sources critically". Points are awarded for determining and using sites meeting the criteria. Librarians continue to develop interesting and interactive methods for teaching information literacy. 


\section{Ever Changing Role for Librarians}

The movie Avatar, a blockbuster movie in 2010, was inspirational in ways inconceivable. Hao-Chang et al. (2011) envision librarians as avatars providing virtual world information services. They describe how important it is for librarians to continually blend traditional library services and resources with today's popular science fiction concepts. They use the term "Second Life librarians" to emphasize the new role and the importance to evolve as quickly as technology expands. Second life is a virtual environment where characters are created much live avatars (Secondlife). Tehrani (2008) suggests there is an advantage to virtual world searching for information. You can "find it faster and easier compared to navigating a Web site" (p. 8).

Finding information faster and easier is now available with the use of handheld devices such as smartphones/iphones/ipads. These are wonderful devices that allow us to get information at anytime, anywhere. You can even connect to the library from them. With such finger-tip access to information we need to become information literate users now more than ever.

\section{Other Progress}

Organizations are taking a stronger position on promoting information literacy awareness and workforce readiness skills. The National Forum on Information Literacy (NFIL) embarked on a campaign in 2012 for statewide awareness. The goal is to get each state in the United States to proclaim the importance of information literacy. At the writing of this article, the NFIL web site lists some 22 states and 1 territory that have issued such proclamation. Another 17 states have proclamation requests in the works (www.infolit.org). The Partnership for twenty first century Skills continues to nationally promote readiness and critical thinking. It currently has 19 states working toward "standards and practices for twenty first century education to prepare students to graduate ready for the challenges of an interconnected global workforce" (www.pil.org). Other research focuses on preparing future employees for the business world. Two Educational Testing Services researchers examined business schools' curriculum for evidence of information literacy. Ali and Katz found limited integration of information and computer technology (ICT) skills. The authors' work places the importance of infusing ICT in the curriculum (Ali and Katz 2010), proof that pre-service training must prepare future employees for the workplace.

\section{Summary}

It is evident that information literacy has begun to emerge as an important skill. Organizations are promoting the awareness of such a need nationwide. Academic librarians are creatively seeking ways to get students to become information literate, integrating twenty first concepts as stimulators for learning. Companies continue to demand a level of readiness that include information literacy and integrated 
ICT skills. Clearly, as technology continues to permeate our lives through handheld smart devices, the access to information will continue the demand that information seekers become information literate users. Perhaps the United States will lead the world in making this demand.

Open Access This chapter is distributed under the terms of the Creative Commons Attribution Noncommercial License, which permits any noncommercial use, distribution, and reproduction in any medium, provided the original author(s) and source are credited.

\section{References}

Ali R, Katz IR (2010) Information and communication technology literacy: what do businesses expect and what do business schools teach? Research Report. www.ets.org/research/contact.html

American Library Association, Presidential Committee on Information Literacy (1989) Final Report. Chicago: American Library Association. Accessed 30 Jun 2013

Association of College and Research Libraries (2000) Standards for information literacy. www. ala.org/acrl/standards

Bailey EC Jr (2010) Educating future academic librarians: an analysis of courses in academic librarianship. J Educ Libr Inf Sci 51(1):30-42. http://ezproxy.pgcc.edu/login?url=http://search. proquest.com/docview/203240096?accountid=13315. Accessed 15 Aug 2013

Branch K, Gilchrist D (1996) Library instruction and information literacy in community and technical colleges. RQ 34(4):476-482. Retrieved October 12, 2006, from Education Full-text

Department of Labor (1992) Secretary's commission on achieving necessary skills. http://wdr. doleta.gov/SCANS/. Accessed 6 Aug 2013

Educational Testing Service (2009) iCritical thinking certification. www.ets.org. Accessed 16 Aug 2013

Hao-Chang S, Chen K, Tseng C, Wen-Hui T (2011) Role changing for librarians in the new information technology era. New Libr World 112(7):321-333. doi:http://dx.doi. org/10.1108/03074801111150459

Head A (2012). Learning curve. Project Information Literacy. Research Report, October 16, 2012. www.pil.org

Hufford JR (March 2010) What are they learning? Pre- and post-assessment surveys for LIBR 1100. Introd Libr Res 71(2):139-158

Mercardo H (1999) Library instruction and online database searching. Res Serv Rev 27:259-265. Retrieved February 14, 2004 from ProQuest Research Library

Naisbitt J (1982) Megatrends: ten new directions for transforming our lives. Warner Books, New York

National Forum on Information Literacy, www.infolit.org

Partnership for the 21st Century. Press release, April 25, 2010. www.p21.org

Secondlife. Secondlife.com

Simmons HL (2000) Librarians as teachers: a personal view. In Bahr AH (ed) Future teaching roles for academic librarians. The Haywood Press, Inc., Binghamton, pp 41-44

Smale MA (2012) Get in the game: developing an information literacy classroom game. J Libr Innov 3(1):126. http://go.galegroup.com.ezproxy.pgcc.edu/ps/i.do?id=GALE\%7CA28853830 $8 \& \mathrm{v}=2.1 \& \mathrm{u}=$ pgcc_main $\& \mathrm{it}=\mathrm{r} \& \mathrm{p}=\mathrm{AONE} \& \mathrm{sw}=\mathrm{w}$. Accessed 6 Aug 2013

Tehrani R (2008) Virtual customer interactions. Customer 26(5):8, 10 (inter@ction solutions)

Vann SK (1978) ed. Melvil Dewey, his enduring presence in librarianship. Libraries Unlimited, Inc., Littleton

Weiner SL (2010) Information literacy: a neglected core competency. Educause 33(1)

Wright AJ (2007) Preservice preparation programs for academic librarians for teaching information literacy. Dissertation. Morgan State University

Zachery I (2008) Psychology 101 Jeopardy!. izachery@pgcc.edu 